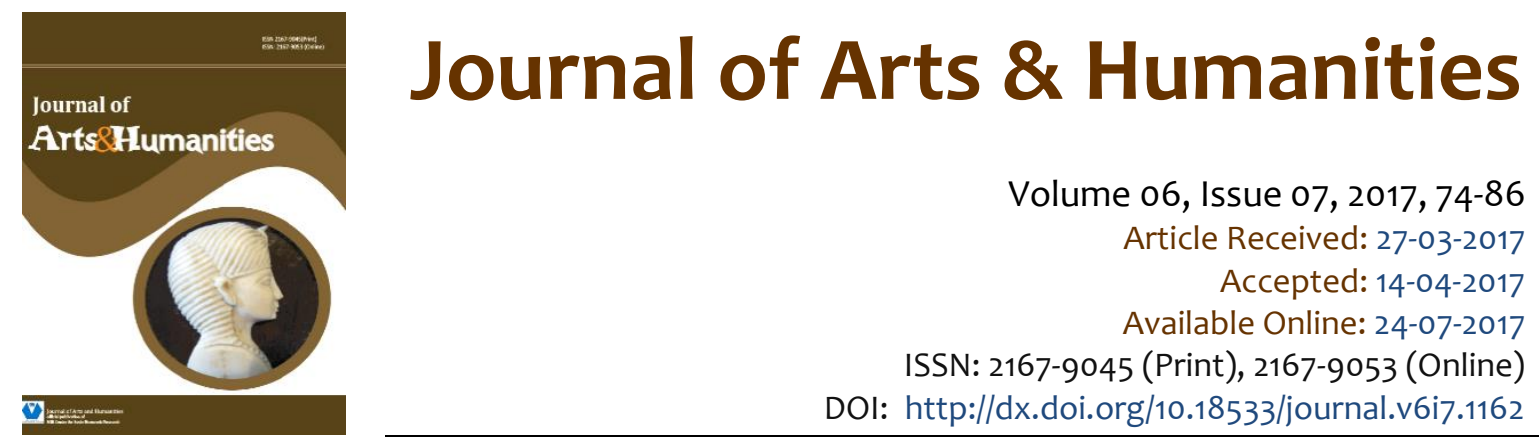

\title{
Exploration of Food Culture in Kisumu: A Socio-Cultural Perspective
}

\author{
Dr. Fredrick Z.A. Odede1, Dr. Patrick O. Hayombe, Prof. Stephen G. Agong
}

\begin{abstract}
Increasingly food culture in the context of socio-cultural dimension is becoming important for sustainable urban development. In the last four years food festivals have been held in Kisumu attracting several interests both from within and without the City. The Kisumu fish night event of 2013 marked the melting point of food culture in Kisumu. This paper thus explores the noble intention of integrating food culture in Kisumu as a socio-cultural capital for the advancement of City sustainable development agenda. To an agrarian society, life is about food from its production, the processing/preservation up to the consumption or the sharing. People connect to their cultural or ethnic background through similar food patterns. People from different cultural backgrounds eat different foods leading to the question: Are Luos in Kisumu defined by their own food culture? This study further investigated the mode of production, and storage of food resources, examined food cuisines of the Luo community in Kisumu, and assessed the food habits, practices and beliefs associated with food cuisines, as well as, the nutritional and socio-cultural values of Luo cuisines. The research employed qualitative methods of data collection such as interviews, observation, focused group discussion and photography using purposive and snowball sampling technique. Content analysis was used to draw general universal statements in thematic areas with respect to the research objectives. The study revealed that Luo community in Kisumu has a food culture laced with rich cultural practices, rituals and societal norms that defines them as a distinct cultural identity but interacts with other cultural groups in the metropolitan city of Kisumu. Further, the study confirms that indeed food culture is vital for sustainable development of urban centre granted that Kisumu largely evolved as urban centre for exchange of goods for food.
\end{abstract}

Keywords: Cuisine, Cultural Group, Food Culture, Food Habit, Kisumu City, Luo, Social Relation.

This is an open access article under Creative Commons Attribution 4.0 License.

\section{Introduction}

The study of food is an emerging interdisciplinary field of study that observes the intricate relationships among food, culture, and society from a number of disciplines in the humanities, social sciences, and

\footnotetext{
1 Jaramogi Oginga Odinga University of Science and Technology, Kenya, E-mail: kansyore@yahoo.com
} 
sciences (Kittler, Sucher, \& Nelms, 2012). Food culture refers to the practices, attitudes, and beliefs, as well as, the networks and institutions surrounding the production, distribution, and consumption of food (Figure 1). It is hard to see why we need a food culture unless we understand what one really is and where it comes from. Certainly those regions that do have their own food culture fully intact might not even recognize the term 'food culture'. Food culture is a connection to food in a pure and deep sense. It is knowing what it takes to bring forth food, rejoicing in times of plenty, and doing all we can to help one another in times of scarcity. It is the conversation around a table three times a day and it is the health given to our bodies from the essence of those plants and animals (Larson \& Story, 2009). Food culture has always existed in various communities, where hours upon hours of tilling, planting, weeding, and sowing are done in order to simply feed the family and neighbours.

It is impossible to have a full concept of food culture if you are not in the business of producing food at some level. Because, to an agrarian society, life is about food, the production of it, the preservation of it, and the sharing of it. People also connect to their cultural or ethnic group through similar food patterns (Figure 1). Immigrants often use food as a means of retaining their cultural identity. People from different cultural backgrounds eat different foods (Stein \& Nemeroff, 1995). The ingredients, methods of preparation, preservation techniques, and types of food eaten at different meals vary among cultures. The areas in which families live and where their ancestors originated, influence food likes and dislikes. These food preferences result in patterns of food choices within a cultural or regional group. Nations or countries are frequently associated with certain foods. Methods of preparation and types of food vary by regions of a nation. Regional food habits do exist, but they also change over time. As people immigrate, food practices and preferences are imported and exported (Figure 1). Families move to other locations, bringing their food preferences with them. They may use their old recipes with new ingredients, or experiment with new recipes, incorporating ingredients to match their own tastes.

Nevertheless, what is considered edible or even a delicacy in some parts of the world might be considered inedible in other parts (Creuziger, 1983). Although food is often selected with some attention to physical need, the values or beliefs a society attaches to potential food items define what families within a cultural group will eat. Some food beliefs and practices are due to religious beliefs (Figure 1). The dietary laws, which describe the use and preparation of

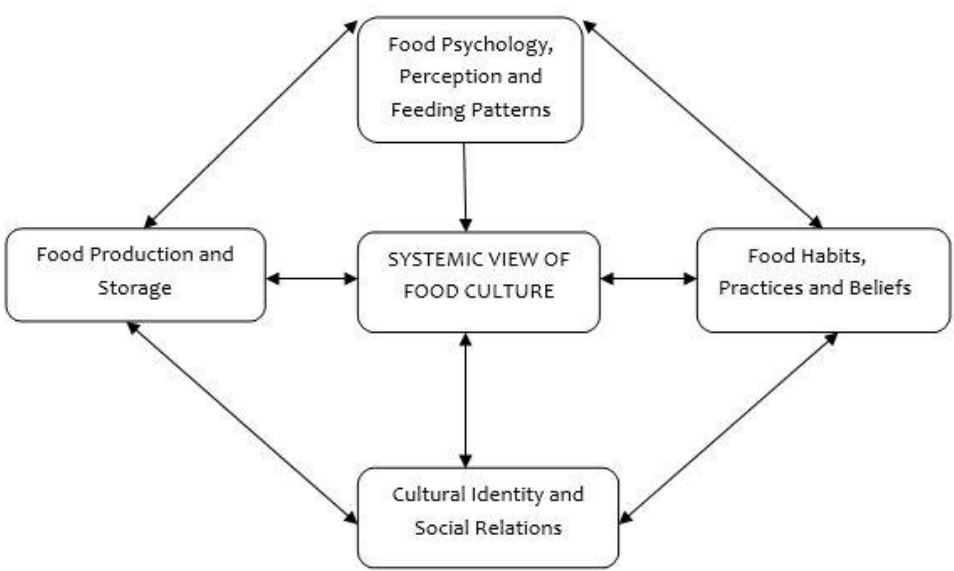

Figure 1: Socio-cultural perspective of food culture in Kisumu.

animal foods, are followed for purposes of spiritual health.

In addition to impacting food choices, culture also plays a role in food-related etiquette. Some people eat with forks and spoons; more people use fingers or chopsticks. The amount people eat and leave uneaten also varies from group to group. Even the role of conversation during mealtime varies from place to place. Food plays an important role in the lives of families in most cultures.

However, the degree of importance varies from culture to culture. The main research objectives of this study include: What is the mode of production, and storage of food sources in Kisumu?; What are the food cuisines of the Luo of Kisumu?; What are the food habits, practises and beliefs associated with food cuisines among the Luo of Kisumu city?; What are the nutritional and socio-cultural values of Luo cuisines?; Does food culture exist among the Luo community of Kisumu city?

The Luo are an ethnic group in Kisumu City of Western Kenya. They are part of a larger group of ethnolinguistically related Luo peoples who inhabit an area ranging from South Sudan, South-Western 
Ethiopia, Northern and Eastern Uganda, South-Western Kenya and North-Eastern Tanzania (Ochieng, 2006; Ogot, 1967).

The Luo are the fourth largest ethnic group (15\%) in Kenya, after the Kikuyu (22\%), the Kalenjin (18\%) and the Luhya (16\%). The Luo and the Kikuyu inherited the bulk of political power in the first years following Kenya's independence in 1963. The Luo population in Kenya was estimated to be 2,185,000 in 1994 and 3.4 million in 2010 according to Govt census. However, the figure was disputed by many Luos as not scientific since a significant portion of people previously considered as Luo were now counted as Suba people. The Subas eventually numbered 300,000 but most are completely assimilated Luos by culture, name, language and political orientation and have more or less the same outlook of life (Ogot, 2009). Sample census conducted by experts estimate the total Kenyan Luo population to be currently at around 5 million.

The main Luo livelihoods are fishing, farming and pastoral herding. Outside Luo-land, the Luo comprise a significant fraction of East Africa's intellectual and skilled labour force in various professions. Others members work in eastern Africa as tenant fishermen, small scale farmers, and urban workers.

They speak Dholuo language, which belongs to the Western Nilotic branch of the Nilo-Saharan language family spoken by other Lwo-speaking peoples, such as the Lango, Acholi, Adhola and Alur (Ochieng, 1971). The four waves of Luo migration were chiefly from the four Lwo-speaking groups (Lwo), especially Acholi and Padhola (Ochieng, 2010). Dholuo, spoken in Kenya, is considered to be proper and standard Luo because it contains elements from all other Lwo languages. The Luo are the originators of a number of music styles, such as Benga, Ohangla, Dodo, Nyatiti, Orutu and Otenga.

This study therefore intends to examine the relationships people have with food, and analyze how this association discloses an enormous amount of information about them. The food choices made by people, either as individuals or as a group, will reveal views, passions, background knowledge, assumptions and personalities. By examining the what, where, how, and why of the food choices and food habits, the study intends to develop a better understanding of the food culture in Kisumu. The aims of the study include an examination of the mode of production, and storage of food sources in Kisumu, identification and inventory the food cuisines of the Luo of Kisumu, establishing the food habits, practises and beliefs associated with food cuisines among the Luo of Kisumu, evaluating the nutritional and socio-cultural values of Luo cuisines and assessing the existence of a food culture among the Luos of Kisumu City. The study was qualitative in nature that employed collection of data through oral interviews, participant observation, as well as, a review of secondary sources. Content analysis was useful in data analysis.

The study findings show that Luo food forms part of their cultural life as the people engage collectively in rituals during crop production and storage. Food consumption is both communal and collective affair. In terms of production, maize is the staple crop. Family members eat together as a sign of communal lifestyle as opposed to individualism. Food restrictions are observed especially among women. Certain types of food are supplementary, used in cases of scarcity. Food also indicates the social status of the family in the society. The feeding patterns and practices, food types, habits and beliefs define Luos as a community within the complex multi-ethnic urban set up of Kisumu City.

\subsection{Research problem}

This study focuses on the urban realm to examine the food culture or food cultures of the multi-racial, and multi-ethnic communities as an appreciation of the value of their cultural identities, cultural beliefs and practices, as well as, social relations within a melting pot of cultures in order to promote social cohesion between diverse ethnic groups and support local livelihood through destination branding of Kisumu as a cultural food destination for tourism promotion for sustainable urban development. Food culture is a new area of scholarly research, particularly in Kisumu, where previous scholars have avoided the question of food culture in the urban set up to enhance community empowerment and support 
local livelihood despite high poverty levels in the area, characterized by consuming urban dwellers rather than producers.

It is impossible to have a full concept of food culture if you are not in the business of producing food at some level. Because, to an agrarian society, life is about food, the production of it, the preservation of it, and the sharing of it. People connect to their cultural or ethnic group through similar food patterns, practices and belief systems. Immigrants often use food as a means of retaining their cultural identity. People from different cultural backgrounds eat different foods (Brillat-Savarain, \& Jean-Anthelme, 2005). The ingredients, methods of preparation, preservation techniques, and types of food eaten at different meals vary among cultures. The areas in which families live and where their ancestors originated influence food likes and dislikes. These food preferences result in patterns of food choices within a cultural or regional group (McComber \& Postel, 1992).

Nations or countries are frequently associated with certain foods. Methods of preparation and types of food vary by regions of a nation. Regional food habits do exist, but they also change over time (Sadella \& Burroughs, 1981). As people immigrate, food practices and preferences are imported and exported. Families move to other locations, bringing their food preferences with them. They may use their old recipes with new ingredients, or experiment with new recipes, incorporating ingredients to match their own tastes. Nevertheless, what is considered edible or even a delicacy in some parts of the world might be considered inedible in other parts. The main questions are: Does food culture exist in Kisumu City? The other research questions of this study include: a) Does food culture exist among the Luo community of Kisumu City? b) What is the mode of production, and storage of Luo food sources in Kisumu? c) What are the food cuisines of the Luo of Kisumu? d) What are the food habits, practises and beliefs associated with food cuisines among the Luo of Kisumu city? e) What are the nutritional and socio-cultural values of Luo cuisines?

\subsection{Research objectives}

i) To investigate the concept of food culture among the Luo of Kisumu City.

ii) To examine the modes of food production and food security among the Luoin Kisumu City.

iii) To identify food psychology and feeding patterns among the Luo of Kisumu City.

\section{Research methodology}

The study was carried out in Kisumu city and its environs (peri-urban), in Kisumu County, Kenya. Kisumu city is located on the eastern shores of Winam Gulf of Lake Victoria. Kisumu County shares common borders with Homa Bay, Siaya, Kakamega and Kericho counties.

Sampling was used to draw conclusions about the entire target population. Non-probability sampling methods such as purposive and snowballing were used to obtain data. Purposive was used because there were some known characteristics like Ministry of Agriculture, Food and Nutrition, Catering Services, Nutritionists from Public Health, Luo Council of Elders, Ker Otondi, Elderly persons eg former mayor Prisca Auma and Grace Onyango, Hotels, Training institutions, Ethnic groups: Luo, Luhyia, Indians, Kisii, Nubian, Kalenjin, Somali; Professionals/Academia, Food companies and factories, Dunga representatives, Miyandhe representatives, Kisumu city representatives, Farmers: Peri-urban: Kajulu, Kano, Food vendors, who were accessed as key oral informants or stakeholders. The key stakeholders were purposively selected to start snowballing sampling process as the key informants directed researchers to the next respondent until saturation point was reached for each research question.

Data collection instruments included interview schedule, observation, focused group discussion and photography. Interviews were mostly done in homes of the oral informants. While a few in their working places. The interviews were done along the research objectives. Observation of the daily life and eating patterns of individual families to examine their social behaviour related to food was also undertaken. This method enabled the researchers to observe directly the food types, and related food 
behaviour patterns and habits in each family. Photography of the various foods was done to complement and illustrate qualitative data collected.

Data analysis involved a synthesis of data based on thematic areas in regard to the research objectives. Content analysis of both secondary and primary data was undertaken by organizing the data into thematic areas and interpreted with respective to the research objectives.

\section{Research findings}

\subsection{Food production, practices and belief systems}

Food crop production was a collective and communal socio-cultural exercise by all family members. No individual member of the family cultivated his land without the participation of other members because land was communally owned. Cultivation was a ritual activity done in ritual sequencing based on seniority of family members with respect to the wives. In polygamous homesteads, the ploughing or land preparation was done in ritual sequence with the senior most household head (from the first wife) taking lead in land preparation followed by the second wife until all the other households in the family had participated, which ensured that everyone in the family had their an adequate food supply. The pattern was repeated in planting of seeds in the farms with the first wife leading as other households followed based on seniority in the family. Even during weeding, it was the family head who first began to weed as other households followed in the same sequence of seniority. During harvesting, no one in the family was supposed to engage in any form of harvesting until the first head of the first wife's house began harvesting. The same process was repeated in harvesting by other houses of the wives based on seniority. All these activities were collectively done by all members of each house wife to ensure that every house in the family produced their food thus enhancing food security in the whole family. Each of the wives had a granary next to her house to store away her grains for future use.

In single families, the concept of socio-ecological engagement in farming took precedence. Land preparation began with the eldest brother followed in sequence with the families of the other brothers. The same applied to planting, weeding and harvesting. All the families of the other brothers cultivated their crops at the same time in ritual sequence to ensure full participation of all family members in order to realise adequate food production ensuring food security of all families. In each homestead, there was nyakurundu (kitchen garden) at the back of every house of every family where afew crops such as maize were grown in small scale but it was dominated by vegetables that were grown for supplementary purposes, enabling continuous food supply in the family.

Fruit trees such as pawpaw, mangoes, bananas, lemon, oranges were planted and available all over the homestead for consumption at any time of the day, which supplemented the nutritional value of the food consumed particularly vitamins to the carbohydrates that were major staple food crops (maize and sorghum). Nyakurundu ensured continuous supply of fruits, hence the food security and balanced diet of the family members were ensured. Most fruits were introduced into the region through long distance trade from the coastal region of Kenya with the coming of the Portuguese who had interacted and collected them from American continent (Table 1). Chicken rearing was done by each and every household in the family. In polygamous families, each wife reared her own chickens while in single families, all the families of the other brothers had their own chickens. Different crops are grown within and in the neighbourhood of Kisumu. The locals tend to have the knowledge of soil fertility and the suited crops for different ecological zones in Kisumu and its environs. The crops that have been grown over the years are millet, cassava, sweet potatoes, maize, bananas, beans, peas, ground nuts and vegetables.

\subsubsection{Sorghum (Sorgum valgare) and Finger Millet (Eleusine Coracana)}

Different clans such as kisumo, kajulu, kano, kanyakwar, and kanyamedha have cultivated sorghum and millet from early times to the present. These crops are grown locally in Kisumu because they are 
tolerant to low rainfall areas. They withstand fairly poor soil conditions such as the dark clay loamy soils of Kano, Kogony and Kajulu areas of Kisumu. They also withstand fairly high temperatures. They are grown by subsistence farmers who cultivate small plots of land during the rainy season of May-June and short rainy period of September-October. They take a period of 4 months to mature for harvesting.

\subsubsection{Cassava (Manihot Utilissima)}

This crop came from South America to Kenya and eventually to Nyanza, and Kisumu where it serves as a reserve crop in case of famine. Cassava is easy to grow because it does not require too much man-hours for crop tending during its lifespan. The locals prefer to grow it because it gives high yields even without much attention. The farmers plant the stem of the crop in the midst of other crops such as maize. Occasionally, the farm is exclusively prepared for cassava planting.

\subsubsection{Sweet potatoes (Ipomoea batatas)}

This is a root crop that reached Kenya and by extension into Kisumu from Latin America. It is a reserve crop that requires more rainfall than cassava and tends to be restricted to the higher areas of Kisumu closer to western province such as Riat, Maseno, and Kajulu. It is a supplementary food crop to the main staple crops such as maize and sorghum in Kisumu.

\subsubsection{Maize}

Maize is a staple food crop in Kisumu, where it is grown extensively. It has its origins from America and was adopted by the locals after introduction by the Asians and Europeans during colonial period. It is consumed by more people in Kisumu than any other food crop. The crop is grown as small scale by subsistence farmers around Kisumu. Maize is grown by subsistence farmers who cultivate small plots of land during the rainy season of May-June and short rainy period of September-October. They take a period of 4 months to mature for harvesting. It is used for preparing Ugali and porridge, the usual food cuisines among the Luo.

\subsubsection{Bananas (Musa spp.)}

They are a staple food crop that is mainly grown in Kisii and Luos of South Nyanza, as well as, parts Alego, Gem and Ugenya and imported into Kisumu from these regions. The crop is grown in areas of high rainfall and well drained fertile brownish loamy clay soils. Patches of banana farms are found along Lake Victoria water front around Kisumu City. The crop takes a long period to mature for harvesting. It is important for preparing motoke usually eaten with meat or taken with tea. Ripe bananas are popular among different groups in Kisumu city as pudding at anytime of the day.

\subsubsection{Beans}

They are planted with other crops like maize. Beans are grown in most parts of Kisumu and acts as a source of protein to the locals. This crop takes a short period to mature thus usually planted after maize farms are already prepared. The crop is grown during long rainy and short rainy seasons by small scale farmers within and around Kisumu. It is used to prepare nyoyo, and oganda dish eaten with rice and occasionally ugali.

\subsubsection{Ground nuts}

These crops are grown in various parts of Nyanza especially along the shores of Lake Victoria such as Kano, Uyoma, Asembo, Sakwa, Karachuonyo, and Suba. The crop has its roots in America. It is grown mainly in Kano and Seme regions of Kisumu. The crop is a source of protein to the residents of Kisumu. It is cooked by roasting or frying for breakfast with uji, porridge and tea. 


\subsection{Cattle, sheep, and goats}

The Luo were a pastoral community where cattle, goats and sheep were reared on communal land. Each family collectively owned livestock but in polygamous homes, the wives were given a number of cattle for milking. Although each wife was given a few cattle, the livestock collectively belonged to the family. Later, the animals were kept on a very small scale due to lack of space for grazing. The animals are sources of meat, blood and milk but are also significant in paying bride-wealth and are indication of a person's social and economic status in the society. They are prepared to produce delicacies such as roasted meat "nyama choma", boiled meat and meat fry that are popular in families and popular feeding joints (hotels) in Kisumu. The meat is eaten with ugali or rice, alongside vegetables.

Food crops are grown by subsistence farmers around Kisumu City who cultivate small plots of land during the rainy seasons of May-June and short rainy period of September-October. Crop cultivation among the locals of Kisumu involves digging, planting, sowing, and weeding as forms of crop tending during its growth using simple tools such as hoes, jembes and ox-driven plough. Most of the crops are left to mature for a period of 4 months for harvesting.

Cultivation is mainly a family affair, where ploughing is done by men while women do light works like weeding and harvesting of crops. During the inception of cultivation, the most elderly person of each family are expected to lead other people in the process of ploughing, sowing, weeding or harvesting as a cultural practice. The first harvest must be eaten by the most elderly and senior member of each family for others to follow. Farming is mainly for subsistence use but the surplus produce is sold in the markets of Kisumu.

In the past, harvested crops were stored in thatched roof and wooden walled granaries constructed during every season of cultivation. The reduction in the farm produce due to limited land, unpredictable rainfall patterns and low soil fertility has led to storage of farm produce in residential houses.

\subsection{Luo food cuisine}

The staple food eaten several times a day is ugali. This is made from maize meal stirred in boiling water until it becomes a thick and smooth porridge. The staple of the community is kuon - which is a meal made with ground flour and used to eat soups and vegetables. Kuon can be made using maize flour, cassava flour, millet flour, sorghum flour or a mixture of all the above. Ugali is made up of ground maize flour and water. It takes the form of a cake after it has been cooked. The cuisine is simply cooked by boiling the flour in water while stirring until it hardens. This is a favourite meal not just for the Luos in Nyanza Province but for all Kenyans. Ugali is always eaten with an accompaniment such as meat, chicken, fish, vegetable or stew.

Greens (sukuma wiki) (Plate 1) and cabbage are frequently eaten with ugali while mito, apoth, osuga, boo and dek are rare traditional vegetable delicacies that have high nutritional value (Plate 2).

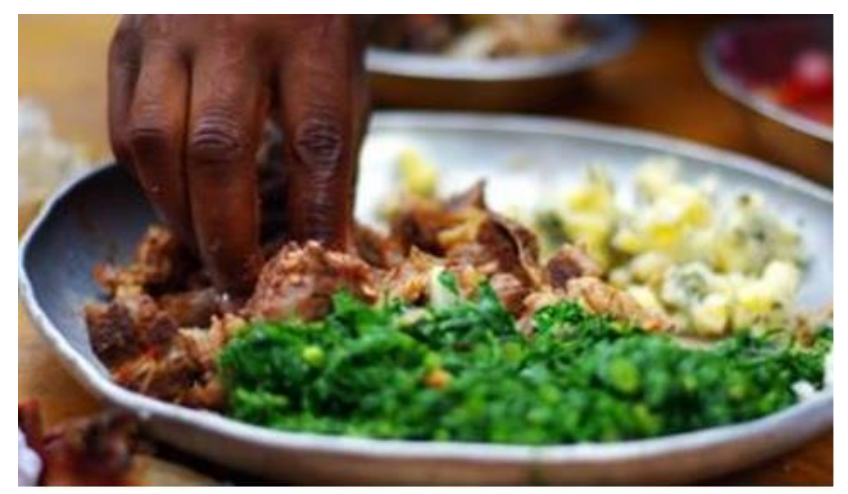

Plate 1: Sukuma Wiki and Nyama Fry.

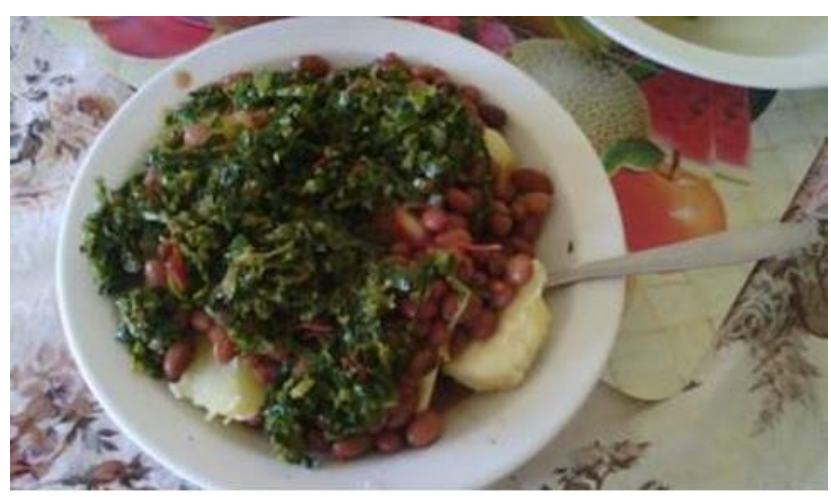

Plate 2: Sukuma Wiki and Beans. 
Growing up in Kisumu, a person eat kuon and vegetables or milk almost every day unlike other communities in Kenya. There is also a joke that regardless of what is cooked for a meal, if there is no kuon then the meal is considered incomplete. The joke has a basis in truth. This is line with Abbots, Emma-Jayne, \& Anna Lavis (2013) argument that the way people eat defines them as a cultural group. Maize, popular throughout Kisumu, is frequently sold for money. This has led many families to sell their maize when financially pressed for money. For this reason, there is a periodic famine throughout Luo land that occurs every year during the long, dry season prior to harvest. The primary crops are maize (corn), millet, and sorghum, all used to prepare kuon (ugali).

One of their favourite meals includes fish especially tilapia, usually accompanied with ugali (called kuon in Dholuo) and vegetables. Many of the vegetables eaten by the Luo were shared after years of association with their Bantu neighbours, the Abaluhya and the Abagusii. Therefore, traditional Luo diet consisted of kuon made of sorghum or millet accompanied by fish, meat, or vegetable stews.

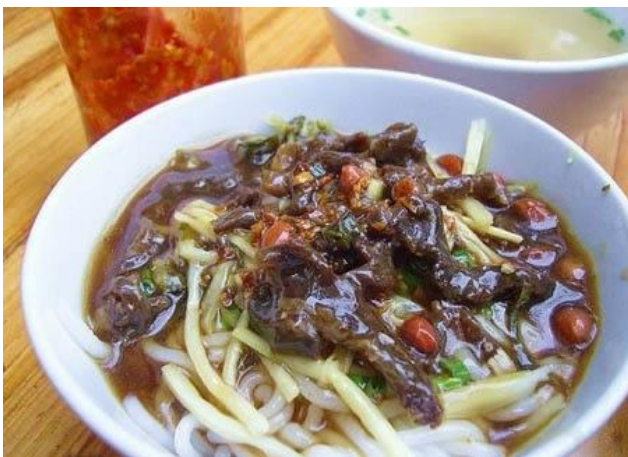

Plate 3: Fried Meat.

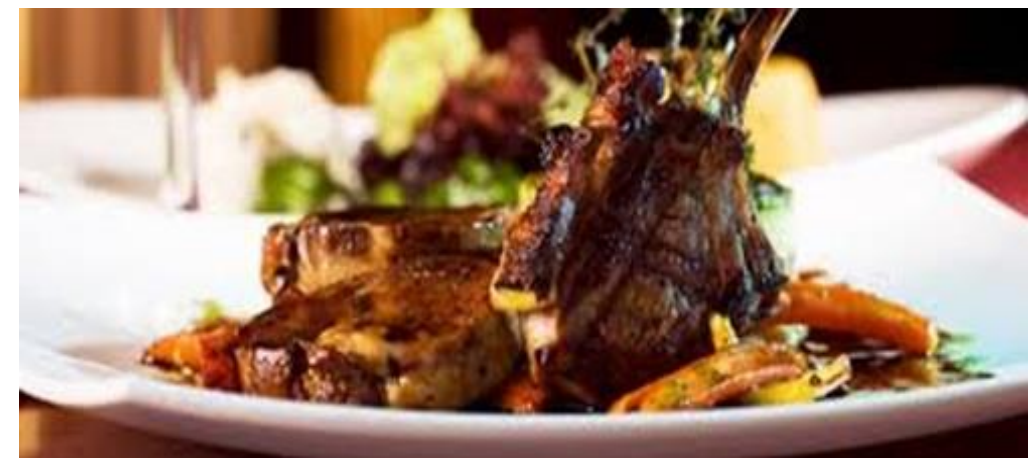

Plate 4: Roasted Meat (Nyama Choma).

Important animals include sheep, goats, chickens, and cattle, which are used as food and for bride wealth. They are important sources of boiled meat, roasted meat and meat fry (Plates 3 and 4). Women in traditional society avoided meat of sheep as part of Luo custom. However, restriction to eat forbidden meats was less for the elderly compared to young women as indicated in Evans, Adrian., \& Mara Miele (2012).

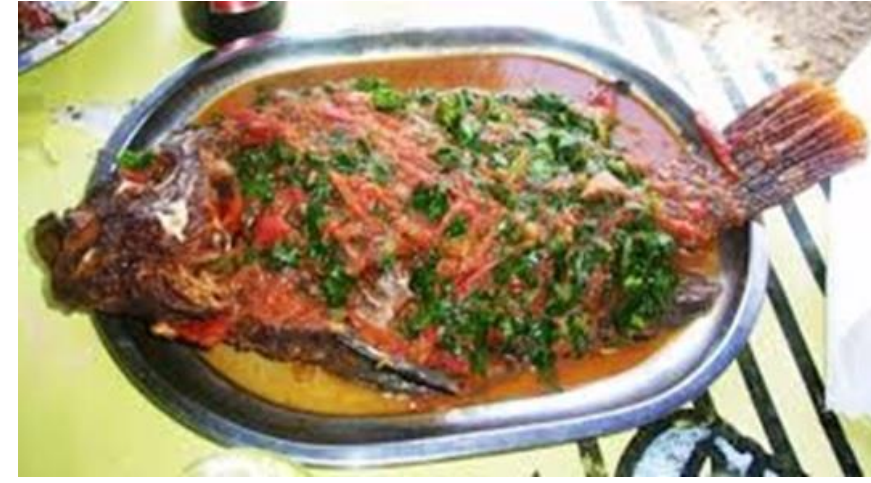

Plate 5: Boiled Tilapia Fish laced with Sukuma Wiki.

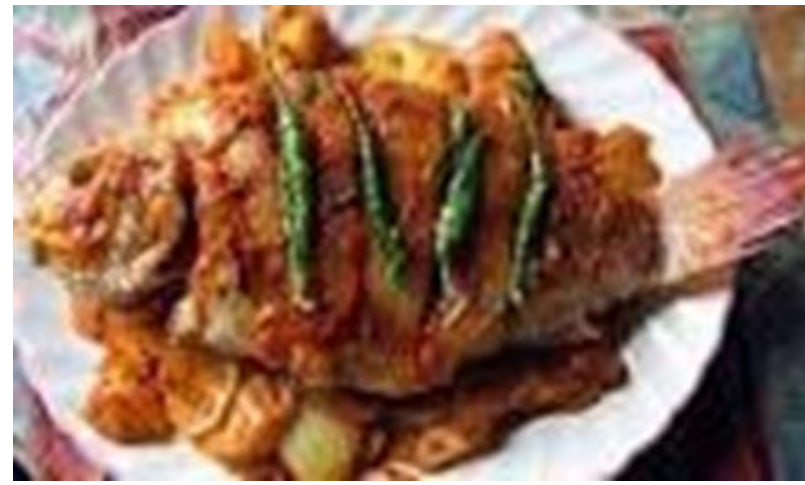

Plate 6: Fried Tilapia Fish.

Fish from Lake Victoria and its streams are important, especially tilapia (Plates 5 and 6), nile patch, omena, mumi, and kamongo, known for their sweetness and aroma. Fish is the main protein food eaten with ugali by most of the families in the area, either during lunch or supper (dinner).

Many foods are purchased, including sugar, bread, and butter, which are consumed with tea on a daily basis, a custom known as "tea time" and derived from the British colonial era, which ended in 1963. The Luos of Kisumu traditionally drank porridge at 10 o'clock in the morning and then had nyoyo, a mixture of boiled maize and beans(Plate 7-below) in support of Lawson (2004). 


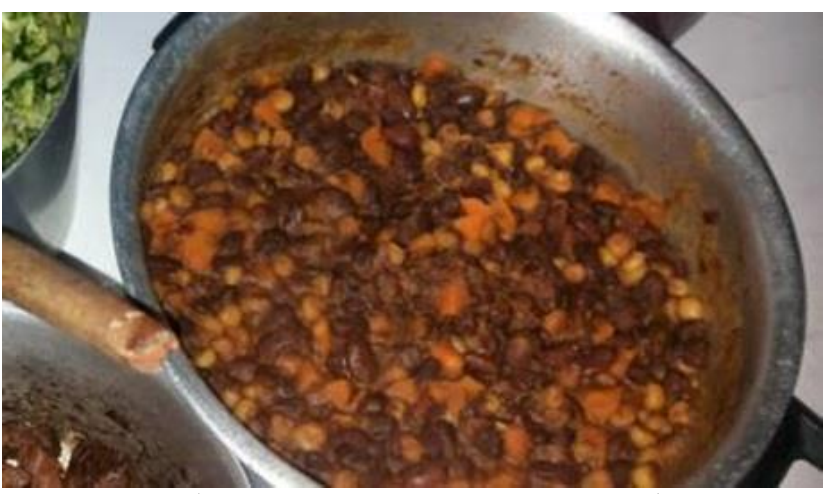

Plate7: Nyoyo (Boiled mixture of maize and beans).

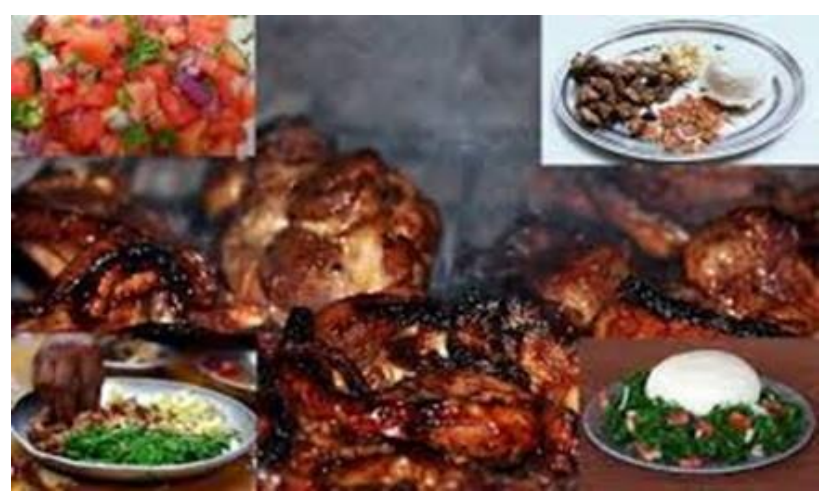

Plate 8: Kuku Choma (Roasted Chicken).

Luos eat chicken, vegetables and ugali during lunch or dinner. Chicken can be roasted, boiled or fried based on local family interest and taste at the time (Plate 8). At dinnertime if the meal is nyoyo (mixture of maize and beans) with porridge, then it is not counted as a full meal but a snack. In order to sleep, one must eat kuon with vegetables or meat or chicken or fish.

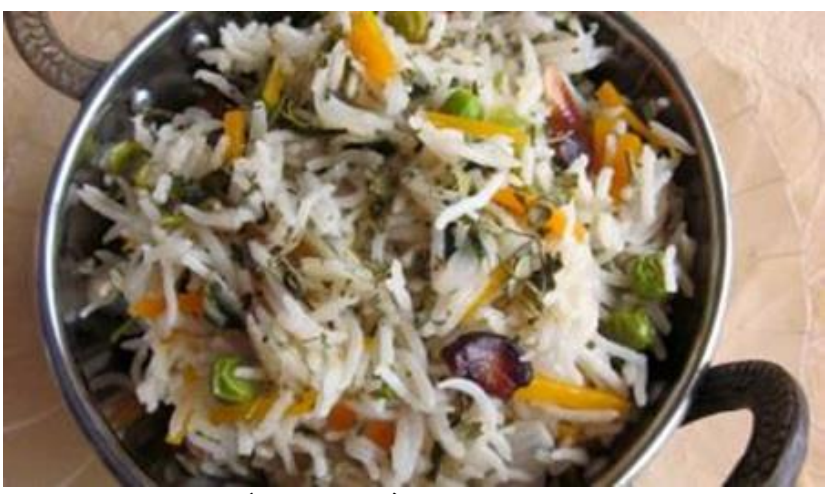

Plate 9: Rice Meal (Boiled rice).

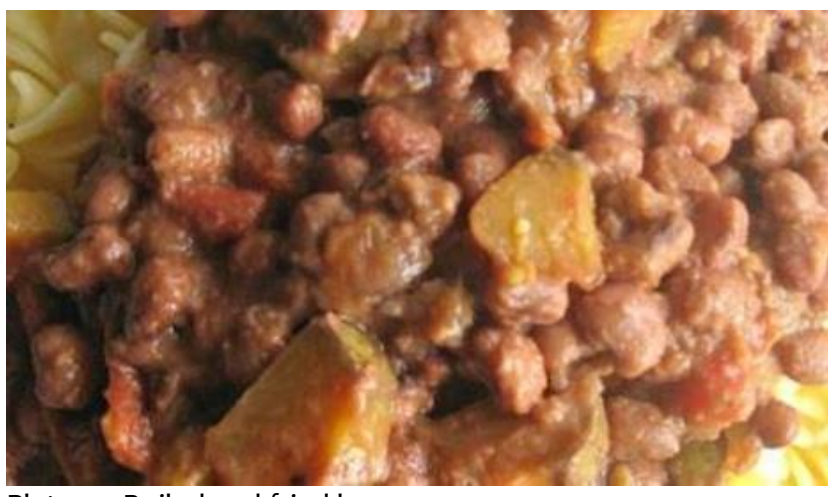

Plate 10: Boiled and fried beans.

This means that Luos eat a lot of kuon, gradually being rivalled or replaced by rice. Rice is locally available from rice farms in Ahero where rice is grown by individual families for sale, as well as, household consumption (Plate 9). An interesting addition was that it is a serious embarrassment (wichkuot) for a Luo to eat sweet potatoes and porridge.

Sweet potatoes, beans and green grams supplemented the diet in case the main meals were not available or scarce due to limited monetary sources (Plate 10). Failure or decline in the produce always necessitates the use of these delicacies among the Luo of Kisumu.

Fruits consumed by Luos in Kisumu include mangoes, pineapples, oranges, bananas, and paw paws that are important sources of vitamins to the populace (Anna, 2013). Some of fruits are grown in urundu within the homestead while others are imported into Kisumu from Asembo, Gem, Ugenya, Busia, Kisii, Kericho, and Luhyaland. Fruits are eaten as pudding after major meals but are occasionally used as a supplement to quench hunger in the course of the day.

\subsection{Food psychology and daily feeding patterns}

Traditionally, there was practice and culture of central eating confined to one place called abila (duol) by all the male members of the family including all male children. Abila was wher the male head of the family took most of his time to talk with his friends and family members. All familiar and clan issues were discussed in duol or abila under the direction of the family male head. The good parts of the food such as chicken were taken to abila for the male members of the family which ensured balanced food diet among the family members particularly the masculine segment since masculinity was expressed in performance of male members as a sign of body physical strength and man power. 
Moreover, different meals were prepared by different households (wives) in the family such that at any given time, food eaten at abila comprised various food delicacies consumed by all male members of the family, which ensured balanced diet. This made all members of the family to enjoy eating at abila where all kinds of food were consumed to avoid malnutrition as the elderly led in story-telling. The happiness index could be observed by the rush of young men on the mention of food availability at abila.

Eating was both communal and collective affair where everyone who was around in the homestead was expected to share the available food at abila. All the other family members such as daughters and wives eat in their houses. Food sharing among family members particularly the wives was seen when one of the wives cooked a special delicacy like chicken, she could give out to the rest of co-wives to enjoy the special delicacy or meal at the same time.

The people who were passing by were invited to join in the family in eating. The Luo of Kisumu did not have strict eating time guidelines to be followed in the day as compared to the present. Some of the foods such as porridge, and milk were available throughout the day to be eaten at any time either by a visitor or a family member, who felt hungry. During the colonial period, the British introduced strict feeding time guidelines on food in the form of breakfast, lunch and dinner based on their industrial background.

Daily feeding patterns among the Luo of Kisumu are characterised by three main meals at different times in the day derived from the British feeding patterns introduced during the British colonial era, which ended in 1963. Early in the morning before people go out to work, the family gathers round a table to take breakfast consisting of tea with bread, chapati or mandazi. Eggs are also eaten during breakfast by the rich families in Kisumu. Occasionally, they take porridge and nyoyo. In the absence of bread, mandazi or chapati, the family consumes potatoes or cassava with tea or porridge (Table 2). It is a common practice among Christian families to pray before meals are eaten as thank giving to God who is believed to be the sale provider.

Table 2: Daily feeding schedule

\begin{tabular}{lll}
\hline Time & Traditional Food & Conventional Food \\
\hline 7.00AM-9.00AM & Uji/Sweet Potatoes & Tea/Bread \\
Ujeakfast & Uji/ Nyoyo & Tea/Mandazi \\
Milk/ Potatoes & Tea/Chapati \\
Milk/Cassava & \\
Milk/ Nyoyo & \\
10.00 AM & Uji/Nyoyo & \\
INTERLUDE FOOD & Uji/Cassava & Tea \\
Milk/Potatoes & Soda \\
Milk/Cassava & Chips \\
& Buzaa & Samosa \\
& Biscuits \\
Dried meat/Ugali & Sweets \\
& Boiled Meat/Ugali & Fried fish/Ugali \\
Roasted Meat/Ugali & Boiled fish/Ugali \\
& Dried Fish/Ugali & Fried Meat/Ugali \\
& Boiled Fish/Ugali & Boiled Meat/Ugali \\
Roasted Fish/Ugali & Baked Meat \\
& Boiled Chicken/Ugali & Chips/Soda \\
Roasted Chicken/Ugali & Chips/Chicken \\
Vegetable/Ugali & Fried meat/Rice \\
& Blood/Potatoes & Boiled Meat/ Rice \\
Milk/Potatoes & Noodles \\
& & Beans/Rice \\
\hline
\end{tabular}




\begin{tabular}{lll}
\hline & Uji/Nyoyo & Green grams/Rice \\
4.00 PM & Uji/Nyoyo & Tea \\
INTERLUDE FOOD & Uji/Cassava & Soda \\
& Milk/Potatoes & Chips \\
& Milk/Cassava & Samosa \\
& Buzaa & Biscuits \\
& & Sweets \\
7.00PM-9.00PM & Dried meat/Ugali & Fried fish/Ugali \\
& Boiled Meat/Ugali & Boiled fish/Ugali \\
& Roasted Meat/Ugali & Fried Meat/Ugali \\
& Dried Fish/Ugali & Boiled Meat/Ugali \\
& Boiled Fish/Ugali & Baked Meat \\
& Roasted Fish/Ugali & Chips/Soda \\
& Boiled Chicken/Ugali & Chips/Chicken \\
& Roasted Chicken/Ugali & Fried meat/Rice \\
& Vegetable/Ugali & Boiled Meat/ Rice \\
& Blood/Potatoes & Noodles \\
& Uji/Nyoyo & Beans/Rice \\
Milk/Potatoes & Green grams/Rice
\end{tabular}

During lunch time, a few members of the family who are left behind assemble to eat heavy meal usually made of kuon, and fish or meat, accompanied by vegetables especially sukuma wiki. The main food courses can further be divided into dried meat and ugali, roasted meat and ugali, fried meat and ugali or rice, as well as, boiled meat and ugali or rice. Meals that encompass fish include dried fish and ugali, roasted fish and ugali, fried fish and ugali as well as boiled fish and ugali while rice is rarely consumed with fish. Chicken (kuku) is a rare delicacy that is taken on certain occasions when there are visitors or during ceremonies especially among the poor urban folk. In the absence of the main meal, the family is forced to take lighter food such as potatoes or cassava with tea, milk or porridge (Table 2). Water, pudding or juice are usually taken or eaten at the end of the feeding session to quench the thirst and to provide the body with a balanced diet particularly among the affluent families (Brown, 2011).

Supper or dinner, are derivative terms obtained from the colonial regime, and are usually taken by all members of the family who assembly around the table to eat and tell their stories of their daily experiences and encounters. Prayers are said sometimes by children as a way of socializing or informal education to be pious Christians and disciple members of the community. The major meals are similar to those taken at lunchtime but variation in food types is observed to realize a balanced diet for the family members (Cumming, 1040). The meals include kuon and meat or fish, kuon and vegetables, but chicken (kuku) is a delicacy that is often encountered in affluent families but least consumed by poor families in Kisumu due to high prices of chicken at the market places (Table 2).

\section{Conclusions}

The Luo food forms part of their cultural life as the people engage collectively in rituals as are observed during crop production and storage for subsistence purposes but at times the food crops are sold for monetary returns in market places. Eating is both communal and collective affair where everyone who is around in the homestead is expected to share the available food at abila. The people who are passing by are invited to join the family in eating. Maize is the staple crop which is used to cook ugali, consumed with fish, meat or vegetables particularly during lunch and dinner. Family members eat together as a sign of communal lifestyle as opposed to individualism. Food restrictions are observed especially among women who do not eat certain types of meat while portions of chicken reserved for men. As Christians, it is a common practice to pray before eating. Certain types of food are supplementary, used in cases of scarcity such as, sweat potatoes, beans, nyoyo and uji. Food also indicates the social status 
of the family since certain foods (chicken, pudding) are confined to the rich of the society. The feeding patterns and practices, food types, habits and beliefs define Luos as a community within the complex multi-ethnic urban set up of Kisumu City.

\section{Acknowledgement}

This paper was developed as a result of Kisumu LOCAL Interaction Platform (KLIP) research project of MISTRA URBAN FUTURES global programme with funds from Swedish International Development Agency (SIDA) in collaboration with Chalmers University of Technology and Gothenburg University in Sweden, Jaramogi Oginga Odinga University of Science and Technology, Maseno University and Kisumu City Council. The agenda of fair and just cities framework for socio-cultural capital while embracing local community participation for poverty alleviation.

\section{References}

Abbots, \& Anna, L. (2013). Why We Eat, How We Eat: Contemporary Encounters between Foods and Bodies. Farnham: Ashgate.

Almerico, G.M. (2014). Food Culture and Habits. Journal of International Business and Cultural Studies, 8, 1-7.

Anna, L. (2013). "The Substance of Absence: Exploring Eating and Anorexia." In Why We Eat, How We Eat: Contemporary Encounters between Foods and Bodies, ed. E-J Abbots and A. Lavis, 35-52. Farnham: Ashgate.

Brillat-Savarain, \& Jean-Anthelme. (2005). "On Taste.” In The Taste Culture Reader: Experiencing Food and Drink, ed. Carolyn Korsmeyer, 15-24. Oxford and New York: Berg.

Brown, A. (2011). Understanding food: Principles and preparation (4thed.). Belmont, CA: Wadsworth. Hauck.

Creuziger, K. 1983. Food in Culture: A course in food habits and attitudes. The Digest. Vol. 5: 1-8.

Cumming, R.O. 1940. The American and His Food: A History of Food Habits in the United States, Chicago.

Elspeth, P. (2000). Carnal Appetites: Food Sex Identities. London and New York: Routledge.

Evans, A. B., \& Mara M. (2012). "Between Food and Flesh: How Animals Are Made to Matter (and Not Matter) within Food Consumption Practices." Environment and Planning D 30: 298-314.

Lawson, A. (2004). Introduction to special issue on the food voice. Food, Culture, and Society, 7 (1), 2425.

Kittler, P.G., Sucher, K.P., \& Nelms, M.N. (2012). Food and culture ( $6^{\text {th }}$ ed.). Belmont, CA: Wadsworth.

Larson, N., \& Story, M. (2009). A Review of Environmental Influences on Food Choices. Annual Behavioral Medicine; 38 Supplement 1; 56-73.

McComber, D.R. \&Postel, R.T. (1992). The Role of Ethnic Foods in the Food and Nutrition Curriculum. Journal of Home Economics, 84, 52-54, 59.

Ochieng, R.W. (2010). A History of Egypt and the Nile Valley from ancient times. Kisumu: Mountain View Publishers.

Ochieng, R.W. (2006). Individual Dreams in Kenyan History. Kisumu: Mountain View Publishers.

Ochieng, RW. (1971). A traditional history of the Gusii of Western Kenya. Unpublished Ph.D thesis, Department of History, Nairobi.

Ogot, B.A. (2009). A History of the Luo speaking peoples of Eastern Africa. Kisumu: Anyange Press Ltd.

Ogot, B. A. (1967). History of the Southern Luo. Nairobi: East African Publishing House.

Sadella, E. \& Burroughs, J. (1981). Profiles in Eating: Sexy Vegetarians and Other Diet -based Stereotypes. Psychology Today (October), 51-57.

Stein, R.I. \& Nemeroff, C.I. (1995). Moral Overtones of Food: Judgments of Others Based on What They Eat. Personality and Social Psychology Bulletin, 21,480-490. 